\title{
ビブリオメトリクスを用いた大学の研究 活動の自己分析
}

\section{Self-analysis of research activity in university by bibliometrics}

林隆之 ${ }^{1}$ |山下泰弘 ${ }^{2}$

\section{HAYASHI Takayuki ${ }^{1}$; YAMASHITA Yasuhiro ${ }^{2}$}

1 大学評価・学位授与機構評価研究部 ( 1 187-8587 東京都小平市学園西町1-29-1)

2 山形大学＼cjkstart評価分析室（=990-8560 山形県山形市小白川町1-4-12）

1 Department of Research for University Evaluation, National Institution for Academic Degrees and University Evaluation (1-29-1 Gakuen-nishimachi Kodaira-shi, Tokyo 187-8587)

2 Office of Planning and Institutional Assessment, Yamagata University (1-4-12 Kojirakawa-machi Yamagata-shi, Yamagata 9908560)

原稿受理 (2011-01-12)

情報管理５3(12), 665-679, doi: 10.1241/johokanri.53.665 (http://dx.doi.org/10.1241/johokanri.53.665)

著者抄録

大学評価の制度化，組織単位の競争的資金の増加，大学の機能別分化など，大学が組織として研究活動の自己分析を 行い，戦略を形成していくことが求められる状況が増している。本稿では，まず国立大学評価の方法を概観し，大学 における研究活動の自己分析にどのような能力が必要となっているかを説明する。その上で，ビブリオメトリクス手 法を用いて，国立大学の法人化以降の日本の大学の状況を生産性や集中度の状況から分析する。さらに，研究分野の 多様性を実現している構造や学内での研究重点化の状況を事例的に分析することを通じて，各大学で求められる自己 分析の視点を検討する。

キーワード

大学の研究活動，研究評価，ビブリオメトリクス，多様性，ポートフォリオ分析

1.はじめに

21世紀に入り，大学の置かれた状況は急激に変化 している。日本についてみれば，戦後以来の高等教 育の大改革と言われる国立大学の法人化が2004年に 行われた。そのきっかけは，高等教育政策よりは， 行財政改革の中で公務員の定数削減を達成するため の一方法であった。しかし，法人化以降，学長の権
限強化や，6年間の目標・計画の策定と定期的な評価 の導入など，国立大学の運営は大きく変化した。一 方で，国から国立大学へ配分される運営費交付金は 毎年減少しており，確実に財政を圧迫している。また， 競争的資金は，従来からの研究者個人を対象とした ものだけでなく，機関や部局単位で計画を立案して 競争的に獲得する資金が増えており，機関単位の戦 略的な対応が求められている。 
大学の変化はこのような日本国内での設置形態だ けではない。社会がグローバル化し，特に雇用もグ ローバル化する中では，大学は国内だけでなく国際 的にも学生獲得の競争を行い，あるいは大学間で連 携していかなければならなくなった。欧州では1990 年代後半より欧州高等教育圏および研究圏を目指し た動きがなされてきた。日本でも東アジアを中心に した大学間連携や研究圏構築の動きが急速に進んで いる。さらに，進学率の上昇により学生が多様化す る中で，教育二ーズは多様化している。経済不況や 高齢化社会や環境問題などの社会的課題に対して， 大学からのイノベーションへの貢献に対する期待は 増すばかりである。大学が果たすべき機能は，拡大し， 多様化している。

このような中で，大学は過去のように，個人や部 局が緩やかに結合された組織では生き残れない。機 関や組織が戦略を有する意思決定主体として，競争 的に資金を獲得し，人材や研究成果を輩出し，国内 外の大学セクターや社会の中でのポジションを明確 化していくことが求められている。研究活動につい ても，大学はその特徵や独自性を自ら分析して示し ていくことで，外部へのビジビリティを高めていか なければならない。

本稿では，まず，大学にどのような自己分析が求 められているかを検討するため，日本の大学評価の 方法を概観する。次にビブリオメトリクス手法を用 いて，国立大学の法人化以降の日本の研究パフォー マンスや研究実施機関の集中化の状況を概観する。 さらに，研究分野の多様性を実現している構造や学 内での研究重点化の状況をトムソン・ロイター社（以 下，トムソン社）のWeb of Science（以下，WoS）と JSTのJDream II のデータを用いて事例的に分析し，大 学の研究活動の特徵をいかに定量的に示しうるか検 討したい。

\section{2. 大学の自己分析能力への要請 : 日本の 大学評価の方法から}

まず，大学評価の状況，特にその中での研究評価 の状況を概説したい。制度として行われる大学評価 は長年安定したものではなく，評価の項目・基準や 評価の方法は，社会から大学への要望を間接的に反 映して構築される。

日本では，大学評価は1991年に大学設置基準の緩 和に伴い「自己点検・評価」が努力義務化されたこ とに始まる。しかし，この時点で行われたことは， 「年報」や「白書」と称して各教員の研究業績を単に 一覧化して示すだけのことも少なくなかった。その 後，自己点検・評価の形骸化が問題視され，2000年 から専門の大学評価機関による第三者評価が導入さ れた。この評価においては，教育評価，研究評価， 全学テーマ別評価の3種類が行われた。研究評価につ いては，学部・研究科等を単位に，9つの学問分野ご とに，研究マネジメント面（組織構成，施策等）と 研究成果面（学術的水準，社会・経済・文化的効果） の評価が実施された。

しかし，2004年に高等教育政策上の大きな変化が あり，代わって新たに2つの評価システムが導入され ることとなった。第一は大学設置基準のさらなる緩 和に伴い，すべての大学は「認証評価」と呼ばれる 第三者評価を受けることが義務づけられた。第二は， 国立大学が法人化され，6年ごとに中期目標・計画 の達成度を評価する「国立大学法人評価」(以下，法 人評価）を受けることが義務づけられた。そのため， 国立大学は少なくともこれらの2つの評価を定期的に 受けなければならない状況にある。このうち認証評 価は教育活動に焦点が置かれており，研究活動の扱 いは軽い。そのため，以下では，法人評価の中での 研究評価について概観する。

法人評価は，文部科学省の国立大学法人評価委員 会が行うものであるが，そのうちの教育・研究面の 評価については，大学自治の尊重の点から，行政府 
表1 国立大学法人評価（教育研究の状況についての評価）における評価項目

\begin{tabular}{|c|c|c|}
\hline 評価の種類 & \multicolumn{2}{|r|}{ 評価の項目 } \\
\hline \multirow{3}{*}{$\begin{array}{l}\text { 法人単位の達成度評価 } \\
\text { (「教育研究等の質の向 } \\
\text { 上」に関する目標) }\end{array}$} & 教育に関する目標 & $\begin{array}{l}\text { (1) 教育の成果に関する目標 } \\
\text { (2) 教育内容等に関する目標 } \\
\text { (3) 教育の実施体制等に関する目標 } \\
\text { (4) 学生への支援に関する目標 }\end{array}$ \\
\hline & 研究に関する目標 & $\begin{array}{l}\text { (1) 研究水準および研究の成果等に関する目標 } \\
\text { (2) 研究実施体制等の整備に関する目標 }\end{array}$ \\
\hline & $\begin{array}{l}\text { 社会との連携, 国際交流等に } \\
\text { 関する目標 }\end{array}$ & （1）社会との連携, 国際交流等に関する目標 \\
\hline \multirow{4}{*}{$\begin{array}{l}\text { 学部·研究科単位の現 } \\
\text { 況分析 }\end{array}$} & \multirow[t]{2}{*}{ 教育の水準および質の向上度 } & $\begin{array}{l}\text { I 教育の実施体制 } \\
\text { II 教育内容 } \\
\text { III 教育方法 } \\
\text { IV 学業の成果 } \\
\mathrm{V} \text { 進路·就職の状況 }\end{array}$ \\
\hline & & 質の向上度 \\
\hline & \multirow[t]{2}{*}{ 研究の水準および質の向上度 } & $\begin{array}{l}\text { I 研究活動の状況 } \\
\text { II 研究成果の状況(「学部·研究科等を代表 } \\
\text { する優れた研究業績の判定」を含む) }\end{array}$ \\
\hline & & 質の向上度 \\
\hline
\end{tabular}

が直接行うのではなく，行政府と大学の間にある中 間組織として大学評価・学位授与機構に委託して評 価が行われることが法律で定められている。法人評 価は，制度上は中期目標期間（6年）終了後に中期目 標の達成度を評価するものであるが，評価結果を第 二期の中期目標・計画の策定や交付金配分に用いる べきという理由から，4年終了時点で評価が行われ た。研究活動に関しては，ほぼすべての国立大学法 人の中期目標には「研究水準及び研究の成果等に関 する目標」と「研究実施体制等の整備に関する目標」 が立てられており，大学は各計画の実施状況を自ら 報告書として提出し，評価委員会がそれを段階判定 し，改善すべき点などの指摘を行った。

さらに，このような目標達成度の評価とは異なる 評価も同時に実施された。国立大学法人評価委員会 の審議において，達成度評価は，大学が立てた目標・ 計画の達成難易度によってそもそも影響されるもの であるため，別途，教育研究の質がどのような水準 にあり，期間中に向上しているかを判断する必要が あるとされ，すべての学部・研究科を評価単位とす る教育および研究の「現況分析」を実施することが 求められた。

研究に関する現況分析は，大きく2項目から構成
された。「I. 研究活動の状況」の項目は，研究の生 産性や共同研究の実施状況に関するものであり，研 究費等の定量的なデータと，学部・研究科自身がそ れらデータも踏まえながら行う自己評価（「現況調査 票」）を用いて評価された。

2つ目の「川．研究成果の状況」の項目では，評価 作業は2つのステップで行われた。まずは個別の研 究業績の判定である。各学部・研究科は，組織自ら が特に優れていると考える研究業績を，教員数の半 数を上限に選定する。さらに，それぞれの研究業績 について，その学術的意義あるいは社会・経済・文 化的意義を，学部・研究科自身が論文引用，受賞， プロジェクト評価結果などの各種の根拠をもとに説 明する資料を提出する。その書類をもとに，ピアレ ビューアーが二次的な評価を行い，実際に特に優れ た業績として認められるかを，SS (卓越)，S (優秀)， それ以外（良好〜相応）の3段階で判断する方法がと られた。

次に，それらの結果を踏まえながら組織レベルの 評価が行われた。学部・研究科は上記の研究業績と は別に，組織としての研究成果についての自己評価 を書面で提出する。評価者は，個別研究業績の判定 結果や自己評価文書を踏まえて，組織全体としての 
研究成果を4段階で判定した。最終的な水準判断は大 学や学部・研究科の多様性促進という点から，「それ ぞれの学部・研究科の想定される関係者の期待に応 えているか」という判断基準がとられた。

この評価において特徵的なことは，第一には，大 学の学部・研究科が，どのような研究成果が優れて いるかを自ら判断し選別しなければならないという， 研究成果の自己分析能力が不可欠とされた点であ る。実際には，工学部のように規模が大きく内容が 多様な学部・研究科では，どのような研究成果が優 れているかを学内で分野を超えて判断することは困 難であったという話も聞く。しかし，組織としてど のような研究成果が優れているかを把握する術を持 たなければ，それを外部に示したり，発展させてい くことはできない。

第二に特徵的であったことは，個々の研究業績を 判断するだけでなく，それらを集積した組織全体の ポートフォリオとしても，自己評価することが求め られた点である。組織としてどのような研究分野・ 領域に取り組んでおり，学術的な成果だけでなく地 域や国際社会への貢献に資する研究も行われている のか。組織レベルで創発する特性についての自己分 析が必要とされた。評価では，すべての大学を一律 に同じ物差しで行うのではなく，大学自身が自身の ミッションやステークホルダーを再定義し，それと の関係から組織としての研究活動・成果を分析する ことが求められたのである。

今後の第二期の法人評価がどのような方法で行わ れるかは現時点では具体化されていない。評価の負 担軽減のために，第一期のような中間時点（4年目） の評価は行われずに，6年後の評価となり，現況分析 も簡素化する方向が示されている注1)。しかし，第三 者による評価が簡素化されても，逆に，大学が定期 的に自己分析を行うという責任が増すことにもつな がる。また，法人評価との関係の有無は現時点では 不明であるが，新たに「機能別評価」や「分野別評価」 の必要性も提案されており，それぞれの大学や学部・
研究科のミッションの明確化とそれに適合した分析・ 評価が求められていく可能性がある。

\section{3. 法人化以降の日本の研究実績をどう見 るか}

上述のような大学評価に限らず，COE (Center of Excellence）のような拠点形成を目指す競争的資金を 獲得するためにも，大学はどのような分野を将来的 に育てていくか，いかに対外的に示していくかを考 えなければならない。このような中でビブリオメト リクス手法は，その限界はありながらも，研究成果 のインパクトを引用面から分析することができ，ま た，組織レベルでの研究成果の全体的な分野構成や 共同研究状況を分析可能である。

以下では，個別大学の事例を扱う前に，まずマク ロレベルで日本の大学セクター全体の状況を概観し たい。特に法人化以降の大学の研究活動がどのよう な状況にあるかを把握し，個別大学における分析の 参考に資したい。

\section{1 日本の論文数は減少したのか}

国立大学が法人化して以降，日本の研究力は増強 したのか。法人化から既に6年が経過し，出版までの タイムラグを考慮してもその影響がデータに現れて きたと考えられるため，最近，いくつかの議論がな されてきた。2010年3月には，トムソン社のEssential Science Indicators（ESI）データから国別の論文数を 計測した結果，5年平均のデータについて2003-07年 期から日本の論文数が「減少している」という報告 をしたブログが話題となり，26学協会のシンポジウ ムでも取り上げられた1)。同年6月にトムソン社が発 表した「グローバル・リサーチ・レポート：日本」 でも，WoSにおける日本の論文数は2003-05年には8 万本を超えたが微減し，ほぼ横ばいで推移している ことを示し，世界に占める日本のシェアは低下して いることを述べている2)。同年12月に科学技術政策研 


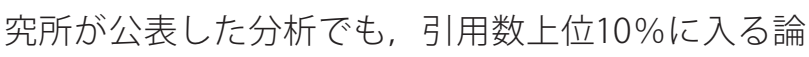
文のシェアが低下している3)。

論文数が減少しているという報告はセンセーショ ナルであるが，使用しているデータや文献タイプ の範囲により結果が異なることや，1年単位の短期 的な増減があるために判断しづらい。特に，Article やLetterやReview以外の種類も含むのかによる影響 もある。WoSでは2008年よりProceedings Paperと いう文献タイプが追加され，以前のArticleの一部が Proceedings Paperに変更されている注2)。その影響の ためか，WoS内のProceedings Paperの収録数は2000 年の10万件から2005年の16万件まで増加した後，減 少に転じ，2009年には8万件と半減している。日本の Proceedings Paperは多い年（2003年）には1万4千件 収録されていたが，それも2009年までに半減してお り，集計值全体への影響も大きい。

そのため，図1には，2010年12月現在で，WoS中 に収録されたArticle, Letter, Reviewのみ (Proceedings Paper等を含まず）の文献数の合計を国別（著者の 所属機関の国）で検索した結果を示している。WOS は，その中のScience Citation Index Expanded（SClexpanded), Social Sciences Citation Index (SSCI),
Arts and Humanities Citation Index $(\mathrm{AHCl})$ の3つの データベースを合わせて用いた。最も論文数の多い 米国は年間30万件前後となるため，図中には日本と 比較が可能な主要国のみを示している。測定の仕方 は，整数カウント（複数国の共著であっても，それ ぞれの国に1本と数える方法）である。

日本は2003年と2005年がやや論文数が多いために その直後には，短期的に減少に転じたように見えて 議論がなされたと思われるが，2008，2009年にはや や増加しており，概して，法人化以降は維持か微増 の状況と見ることができよう。しかし，WoSデータ ベース上の全論文数に対して比率（シェア）を求め た結果（図2）では，中国やその他の新興国の台頭 によってデータベース上の論文数が増加したため， 2003年以降の日本のシェアの減少は顕著である注3)。 共著を分数で計測するかや， SCl-expanded以外の $\mathrm{SSCl}$, AHClを含めるか否かで結果は異なるが，上記の 条件においては，中国やドイツに論文数は抜かれた 状況である。集計方法等による違いはあっても，日 本の相対的な地位が低下していることは確かであろ う。

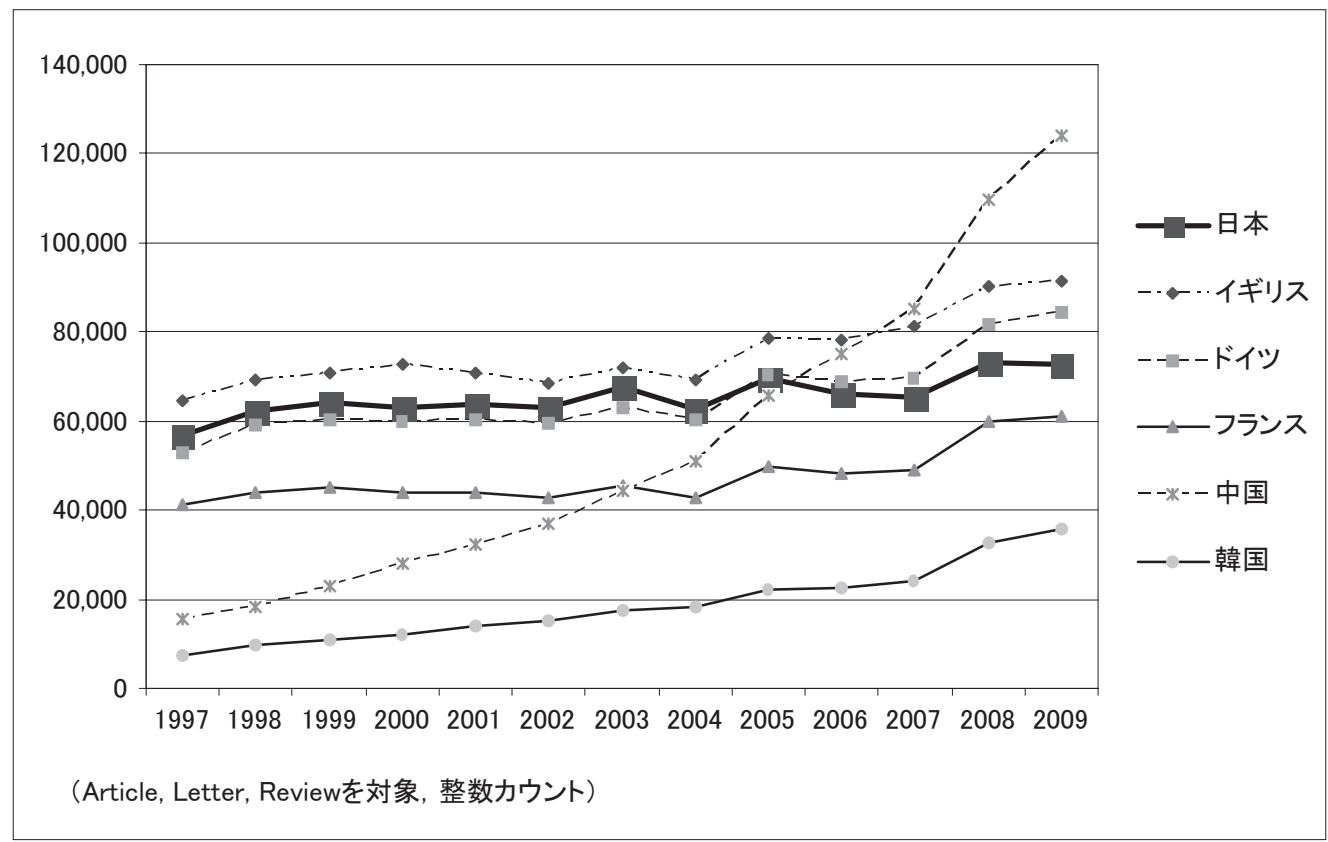

図1＼cjkstart各国の論文数の推移 


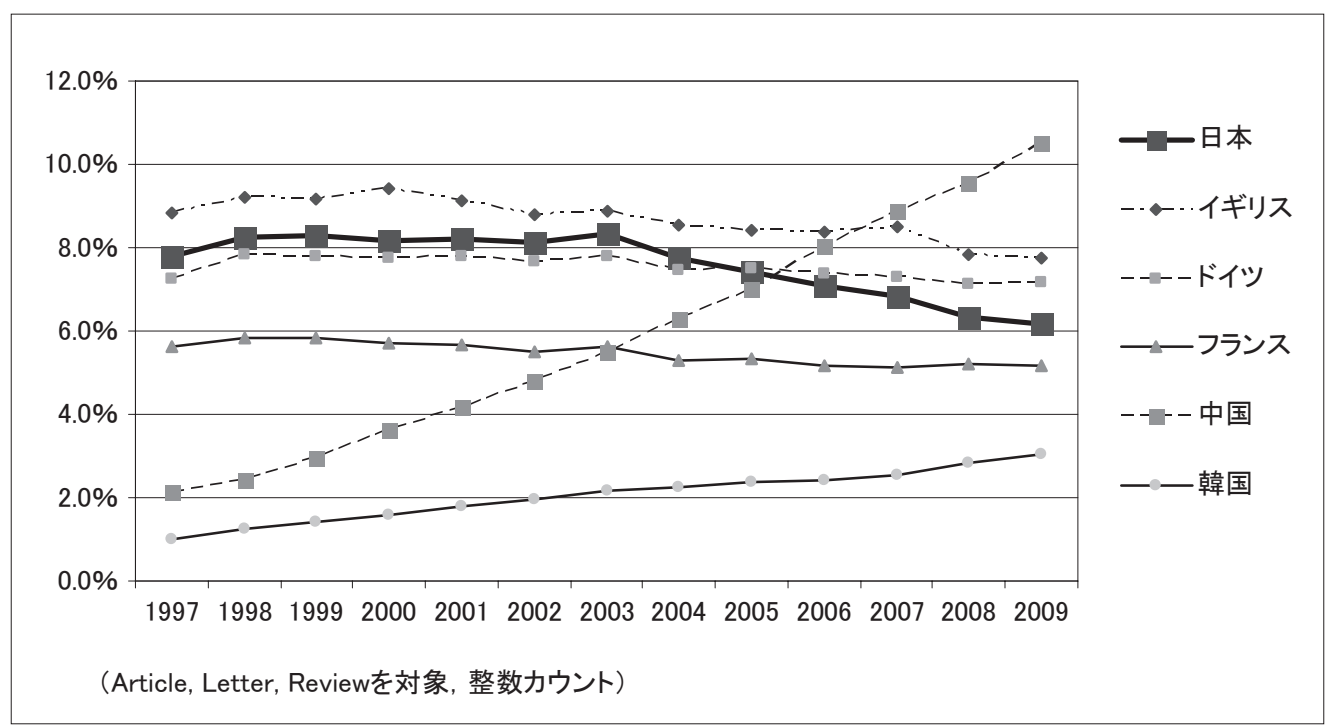

図2 各国の論文数のシェア

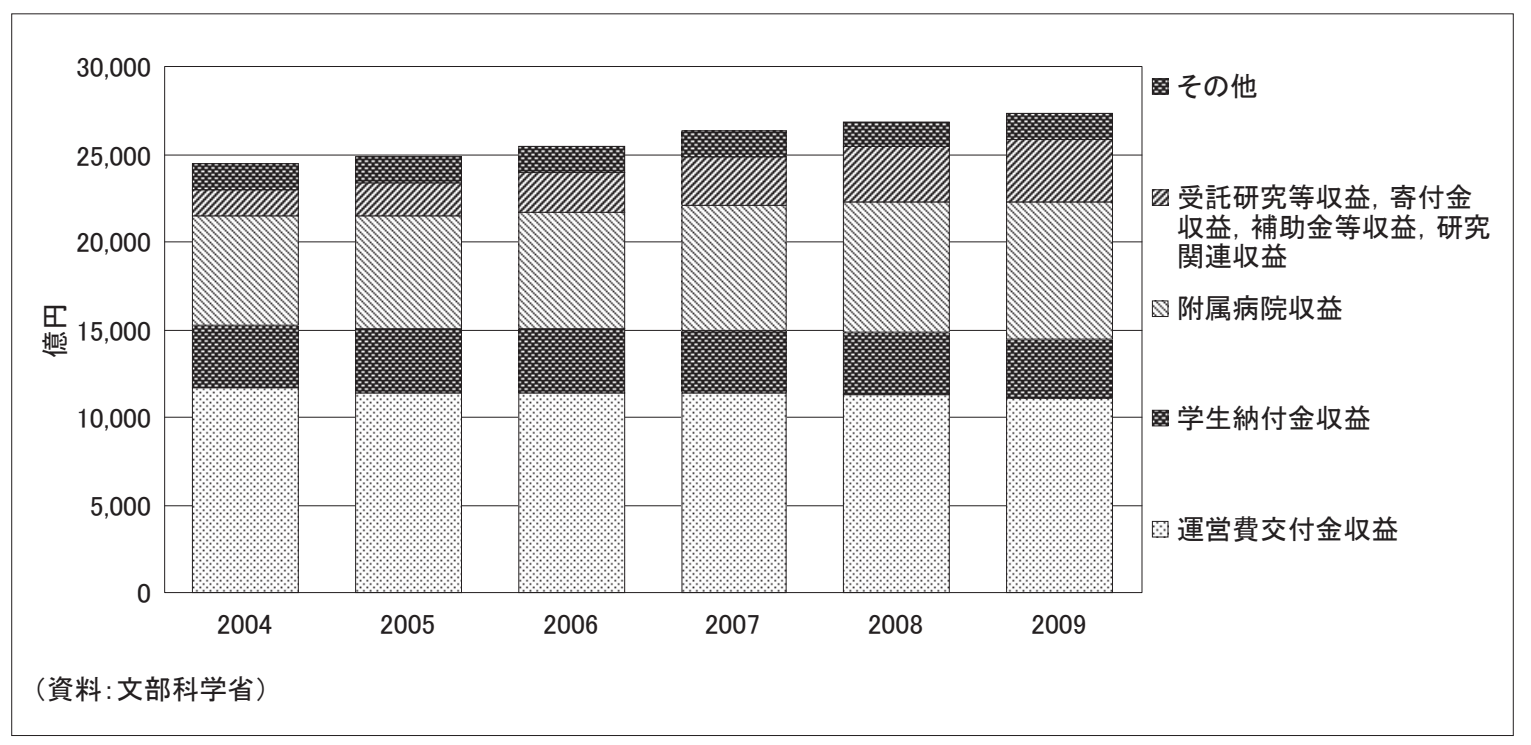

図3国立大学の経常収益

\section{2 国立大学法人化以降の特徵}

では，日本の論文生産の多くを占める大学セクター の状況，および，その内部構造はどのようになって いるか。しばしば指摘されてきたことは，運営費交 付金が減少し，競争的資金が増加することによって， 論文数などで上位に位置する，いわゆる研究大学に 資金が集中するようになり，格差が生じているので はないかという懸念である。

そのため，まず論文数を見る前に，インプット側 である資金を確認しておきたい。図3は法人化以降
の国立大学全体の収入の推移を内訳を含めて示して いる。確かに，国立大学の収入のうちで運営費交付 金の割合は減少しており，病院収入や，受託研究収 入等の競争的に獲得する研究費が増えている。また， 財務諸表の経常費用のうち，広義の研究経費（研究 経費，受託研究費等，科学研究費補助金等の合計） を全国立大学について総計したのが図4である。研 究経費自体は増加しており，上位の8大学（旧7帝大 である北海道大学，東北大学，東京大学，名古屋大 学，京都大学，大阪大学，九州大学，と東京工業大 


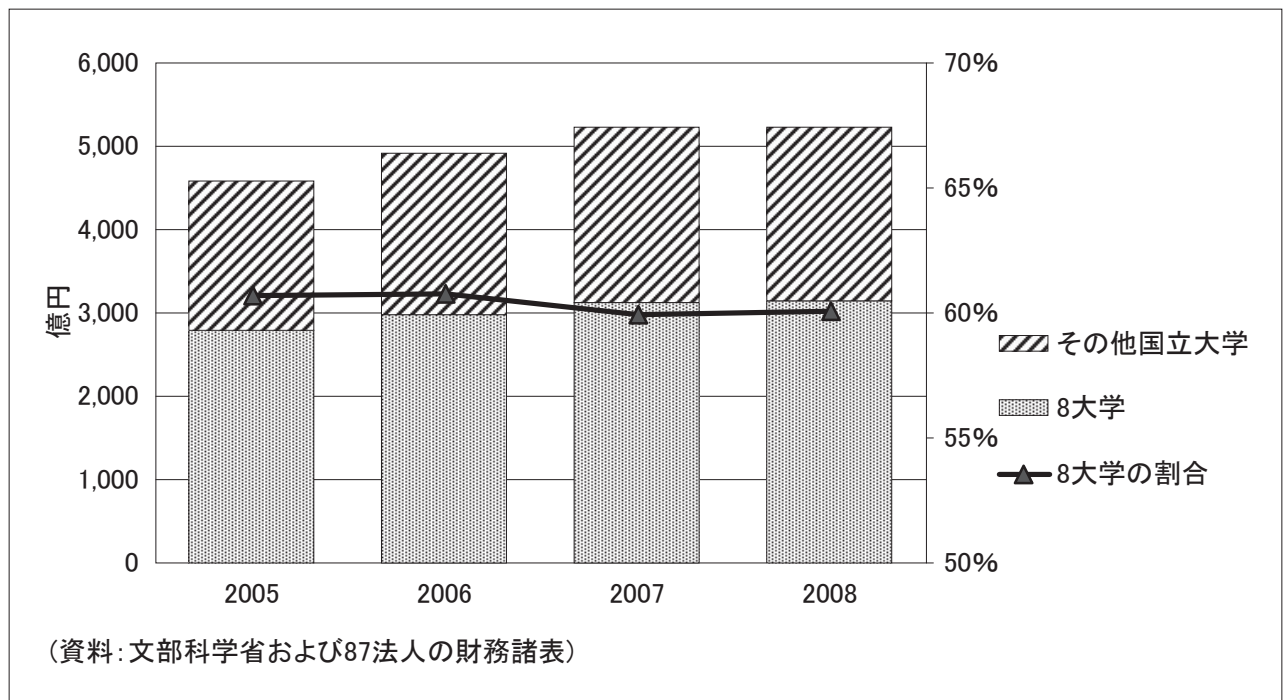

図4 研究経費の推移（研究経費十受託研究費等十科学研究費補助金等）

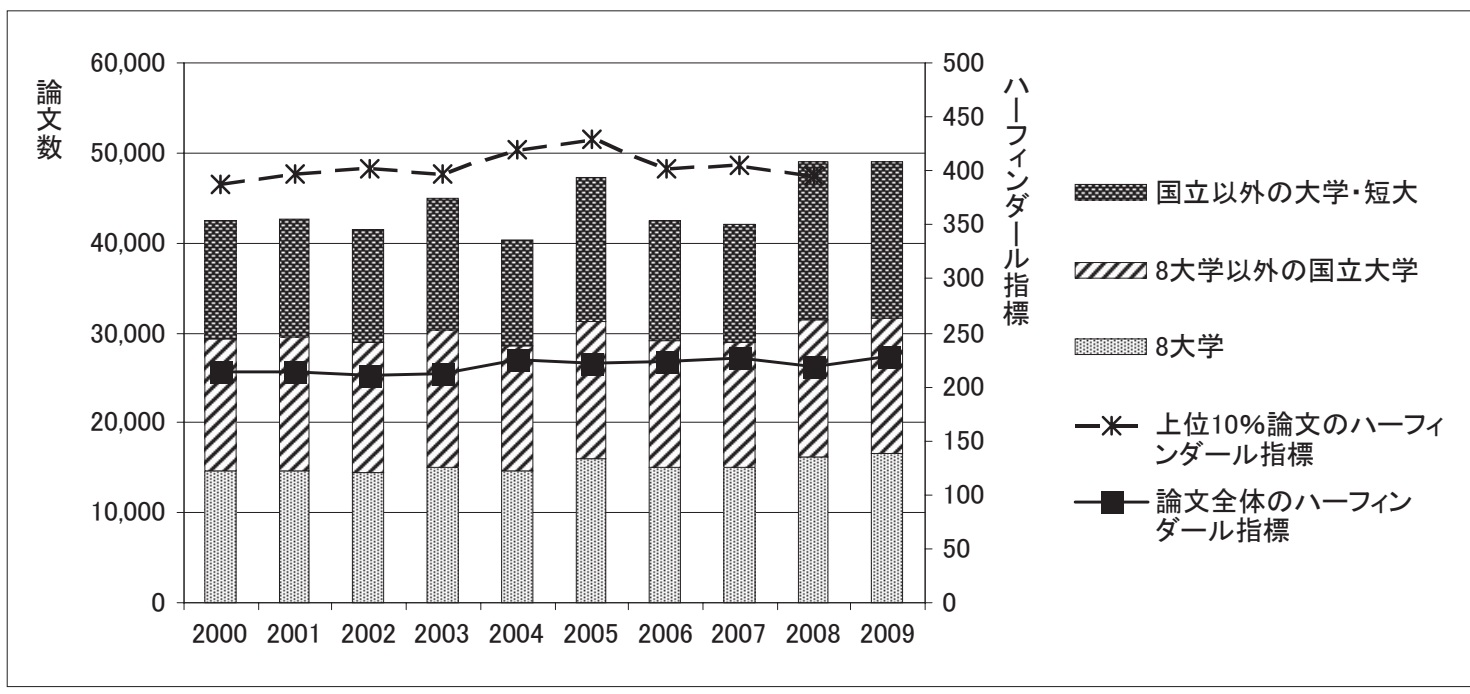

図5 大学セクターの論文の機関構成の推移

学）だけでそのうちの6割以上を占めているが，割合 は4年間で微減であり，格差が広がっていると言える 状況ではない。

ではアウトプットである論文数についてはどう か。筆者の一人は過去に1980年代から2002年までの 大学の論文数を分析した。その中で，1980年代から 集中度指標（ハーフィンダール指標注4)）が減少し， 多くの大学が研究論文を出すようになるという分散 化傾向が進んできたが，競争的資金制度が増加した 1995年頃より分散化傾向が止まり，特に引用数が高
い論文において上位大学の研究者が著者に含まれて いる割合が微増している状況を示した5)。

図5は2000年以降，日本の大学セクターからの論文 数とその中での，8大学の割合を示している注5)。こ こで，複数の機関による共著論文は分数で集計して いる。また，図中には，論文全体と引用数上位 $10 \%$ のそれぞれについて，集中度指標の推移を，線グラ フで示している。ただし，引用期間が十分でないため， 2009年の上位10\%論文の集中度指標は示していない。

結果，全体的に顕著な変化は見られない。上位の8 
大学は一貫して大学セクターのうちの33〜36\%の研 究論文を生産しており，明確な上昇傾向ではない。 集中度指標は，2004年以降の数年間は，論文全体お よび引用数の高い論文ともに，やや上昇している。 すなわち論文全体では2000年に214が2007年には227 になり，引用数上位 $10 \%$ 論文において，2000年に 387が2005年には429と最も高い值となっている。し かし，これらも大きな変化と言えるものではない。
だが，その中身にはやや変化がある。図6と図7は 上位8大学と，それ以外の国立大学の2つの群に分け て，その論文を引用数のグループごとに分けて世界 シェアを示した。すなわち，WOSでは250程の分野分 類があり，各論文には1つ以上の分類が付与されてい るが，各論文が同じ分野分類の同じ年に出版された 同じ文献タイプ (Article, Letter, Review) の論文群の 中で，2010年12月までの引用数に関して，上位10\%

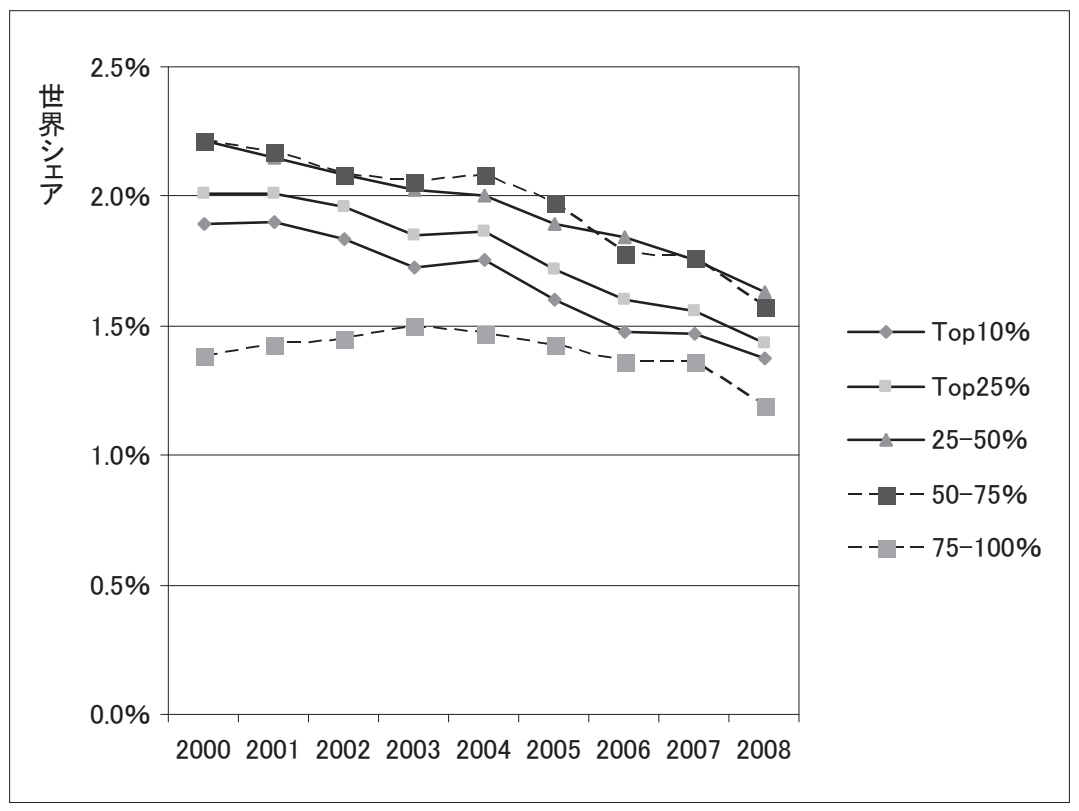

図6 引用グループごとの論文シェアの推移（8大学）

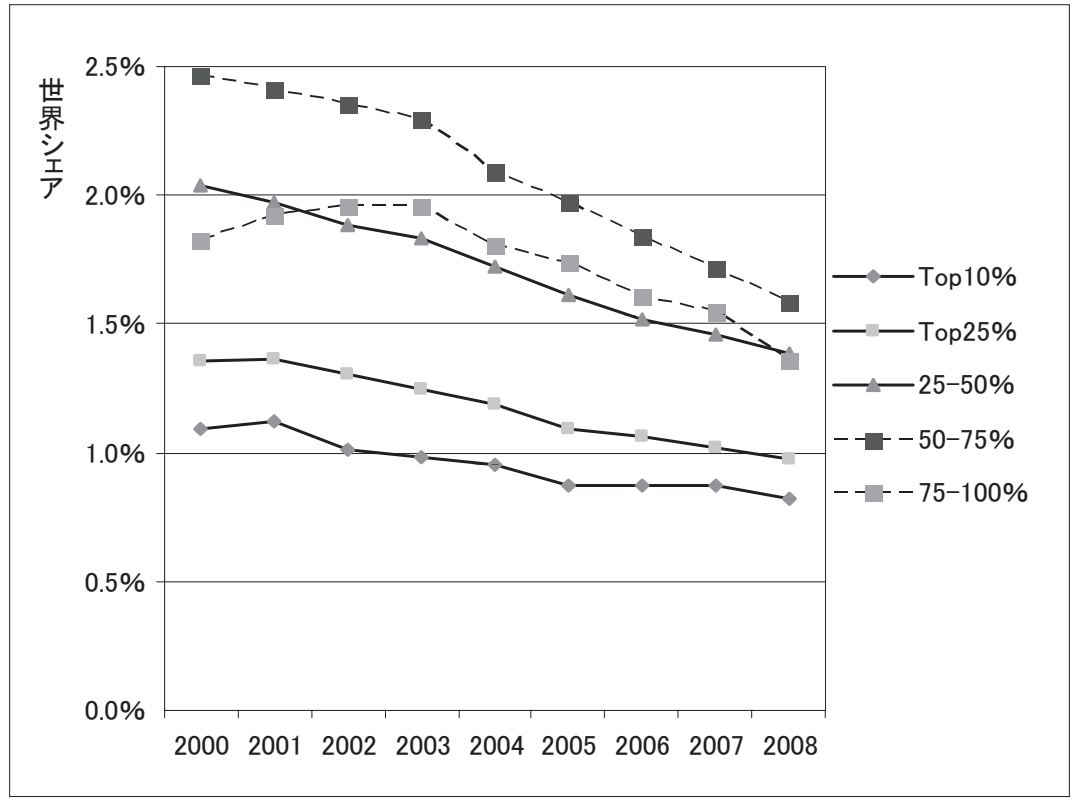

図7 引用グループごとの論文シェアの推移（8大学以外の国立大学） 
以内に位置するか，上位25\%以内か，25-50\%か， 50-75\%か，75-100\%かの論文グループに分けた。そ の結果を大学でとに集計し，グループ内での世界シェ アを示したものである。引用数のパーセンタイルは トムソン社のESIなどで確認できるが，WoSにおいて も，分野名で検索をかけて，それを引用数でソート することによって，何回引用されればどの論文グル一 プに入るかは，簡便に確認することができる。なお， 集計においては，複数の分野が付されている場合は， 分数で集計した。

結果からは，日本全体の傾向（図2）と同様に，各 グループでシェアは低下している。しかし，減少傾 向はやや異なる。上位8大学においては，一つを除 いてすべての論文グループで減少率はほぼ同じであ る。しかし，75-100\%のグループ，つまり，ほとん ど引用されない論文グループについては，そのシェ アは2000年代半ばまでは，他の論文グループより大 きく低かったものが，シェアが減少していない。す なわち，引用されない論文が相対的に増加している ということになる。

他方，上位8大学以外の大学でも全体的に減少傾向 はあるが，その中でも相対的に減少率が低いのは上 位10\%や25\%と，75-100\%グループである。引用数 50-75\%のような少数回のみ引用される論文は減少し ている。

これらの原因は別途詳細な分析が必要となる。上 位の大学にポスドクなどの若手研究者が集中するこ とによる引用数の低い論文が増加していることや， それ以外の大学において研究力が向上し引用数の高 い論文のシェア減少率が低いことなどが考えられよ う。

以上のように，法人化以降，研究費や研究論文に ついて集中化や格差が明確に見られるという結果は 得られず，比較的に安定した構造である。規模の大 きな上位大学以外の大学の研究力に向上傾向がある ことも示唆される。ただし，個別の大学単位でみれば， 上位8大学の中にも，それ以外の大学の中にも，分析
対象の10年間で論文数が減少した大学も増加した大 学もある。すなわち，規模の大きな研究大学である か否かという区分によらず，個別の大学単位で，戦 略的に資金を獲得して成果を産出している大学もそ うでない大学もあることになる。そのため，各大学 が全体傾向の中でどのような状態にあるかを確認す ることが求められよう。

\section{4. 大学の特徵の明確化}

現在の日本の高等教育政策上の一つの焦点は，大 学の「機能別分化」である。中央教育審議会での現 在までの議論では，米国のカーネギ一分類注6) のよ うに，大学単位で研究大学や教養大学といった区分 をすることが目指されているのではない。各大学は， 世界的な教育・研究や，教養教育，地域の生涯学習 拠点など，多様な機能を同時に担っており，大学に よってそれらの機能の重点の置き方が異なり，結果 として，「雑木林」のように分化が達成されるという イメージが示されている。

「機能」の概念は多様であり，今後検討が深められ ていくと思われる。ただ，議論の前提にあるのは， すべての大学が「ミ二東大」を目指す単一の大学モ デルではなく，各大学がその特徵を明確化し，より 資金を重点化し，差異化を図っていくことが求めら れていることである。

研究活動については，そもそも研究活動自体をど れほど行うかや，地域連携や国際共同など，活動の 種別化を行うことができる。これらの実態も共著傾 向などから分析できよう。一方で，大学がどのよう な分野の研究に焦点をおいていくかという論点もあ る。以下では，各大学が日本の大学セクター全体の 中でどれほど特殊性を有しているかという点と，学 内でどれほど重点化しているかという点を検討して みたい。 


\section{1 研究分野の多様性の担い手は誰か}

基礎研究は元来その多様性が求められる。いかな る研究が社会的課題に資するか，新たな研究の発展 に結びつくかの不確実性が高い中では，多様性を確 保することが不可欠であるためである。実際，さま ざまな研究分野をすべての大学が同じように担って いるわけではない。大学によって研究分野に特殊性 がある場合もあり，それゆえに拠点化などが行われ， それが各大学の存在意義の明確化にもつながってい $<。$

ある研究分野がどれほど多数の大学によって行わ れているのか，あるいは，一部の少数の大学のみに よって担われているのか。これは分野ごとに集中度 指標を計測することに等しい。図8は，WoS内の日本 の大学の論文を対象にして，横軸に各分野における 研究実施大学数の集中度指標をとり，縦軸には論文 数の多い8大学の割合をとり，そこにWoSの分野をプ ロットした。プロット円の大きさは論文数に比例さ せている。

図では，左下ほど集中度が低く，8大学の割合も
低い。ここには医学分野が多く存在し，これらは多 数の大学で研究活動が行われていることを示してい る。右上へ行く直線に多くの分野が存在しており， 集中度が上がるとともに8大学への集中が増えてい くという傾向である。ライフサイエンスや工学が中 間に多く，自然科学分野が右上に多く存在する。右 上には，地球化学・物理，海洋学，気象学，天文学， 原子物理学など，巨大な装置や施設を用いる分野が あり，これらの分野は8大学を中心として日本国内で 維持されていると見られる。

その一方で集中度は高いが8大学の割合が低い分 野が右下に存在する。これらは歴史的な経緯もあり， 大規模大学では行われずに，他大学で行われている 分野である。例えば，図書館情報学，緊急医療，イメー ジングサイエンス，歯学，獣医学，および社会科学・ 人文学の各種の研究分野（教育心理学，宗教学等） がある。これらの分野は特定の大学によって支えら れ，中小規模の大学でも特徵や他大学との差異を主 張しやすいものである。大学はその存在感を高める ために，これらの分野をさらに重点化していくこと

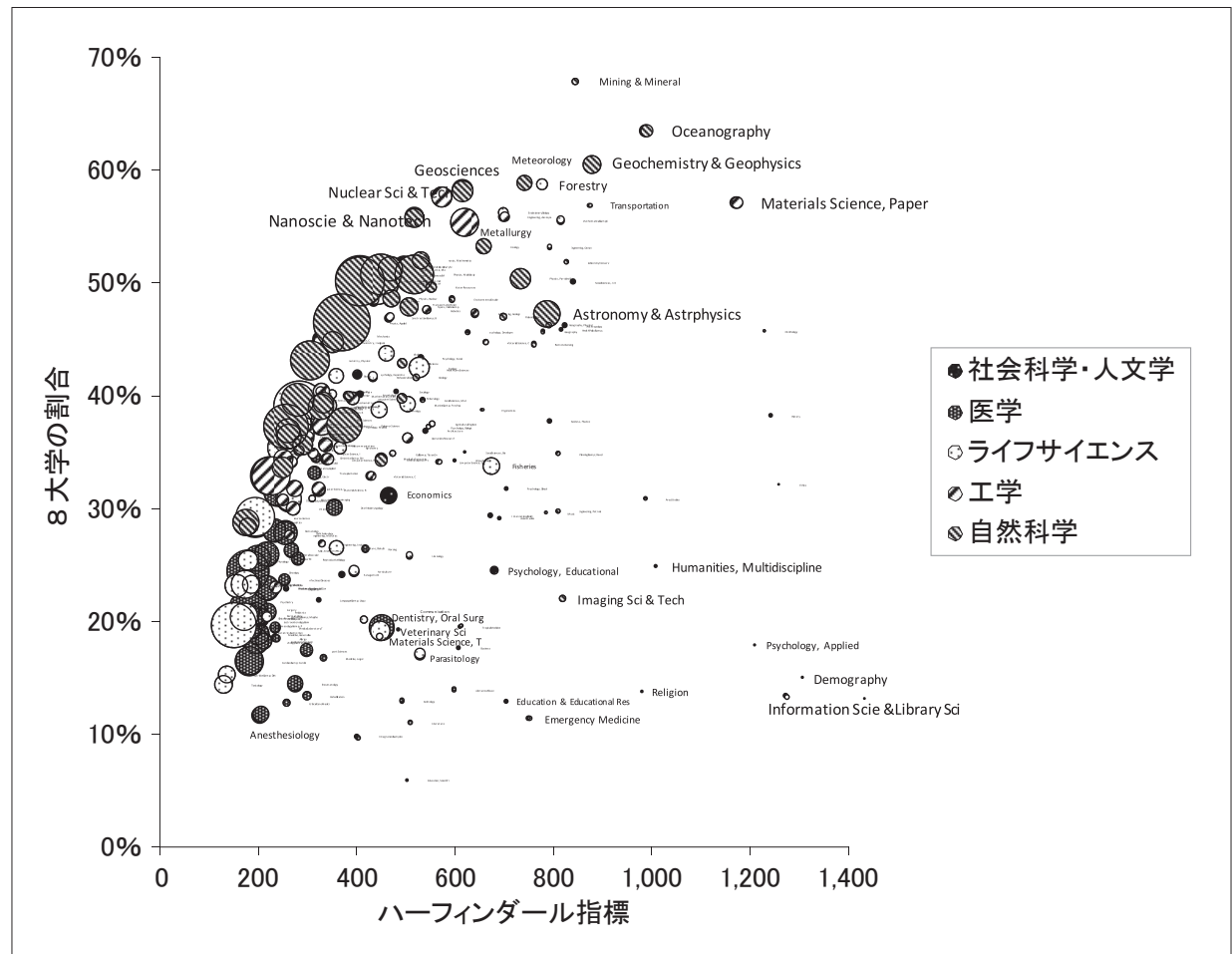

図8研究分野ごとの研究実施大学の集中度（2007-08） 
が考えられよう。政策的には，研究資金の集中化が 一部の大学に進むことがあれば，一つには左下に位 置する医学分野など，現在さまざまな大学によって 担われている分野は縮小し，研究内容の多様性が減 じることが示唆される。さらに，右下にあるような 分野はその存在自体が日本からは失われてしまう可 能性があり，分野の特性を意識した政策が必要とな る。

\section{2 大学の中の重点化の変化}

他方，大学内では法人化以降に研究内容の重点化 が進んでいるのか。例えばCOEなどの拠点化を図る 研究資金制度は大学に変化を及ぼしてきたのか。図9 は，1998-99年と，2007-08年の二時点で，学内の研 究内容の集中度指標を比較したものである。これま では八ーフィンダール指標を用いてある分野の中の
大学の多様性を計測してきたが，逆に，一つの大学 の中の分野の多様性を同じ指標を用いて計測する。 図中で斜めの線より上位にある場合は，二時点間で 集中が増しており，特定の分野の論文数が増えてい ることになる。なお，プロット円の大きさは2007-08 年の論文数に比例させている。

結果は，重点化が進んだ大学は少数であり，多様 化が進んでいる大学のほうが多い。特に規模の大き な大学では多様化傾向がある。その一方で，データ 結果からは（大学自身に明確な戦略があるのかは不 明であるが)，一部の大学は少数の研究分野への集中 （重点化）が見られ，山形大学，東京医科歯科大学， 静岡大学，長岡技術科学大学などがあげられる。

\section{3 大学内部の分析事例：山形大学}

重点化している大学の一例として，筆者の一人が

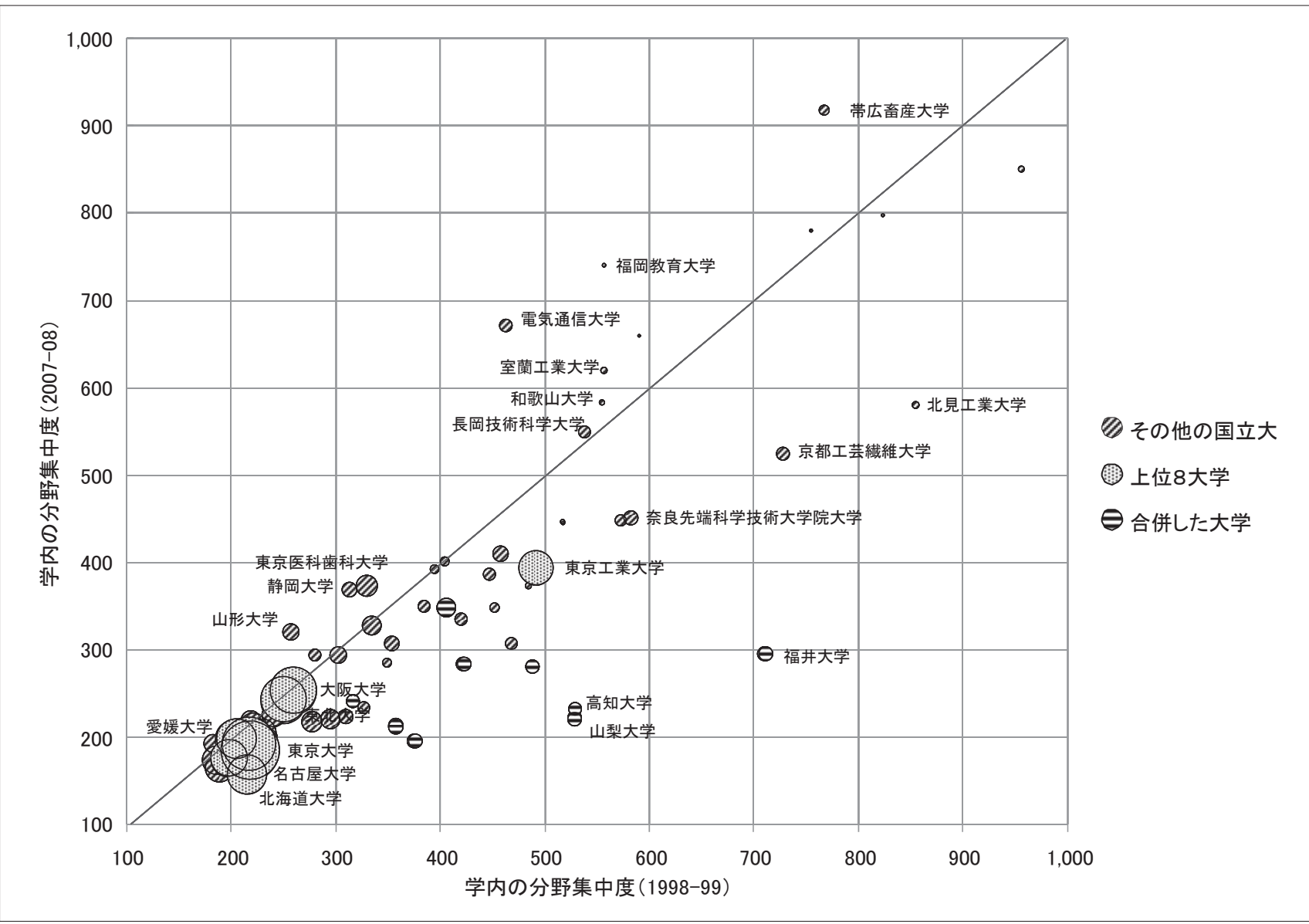

図9 大学内の分野の多様性の変化 
所属する山形大学を見てみたい。山形大学は，WOS において共著を分数カウントした場合には，二時点 間で論文数がやや減少しており注7)，結果的に消極的 な重点化という要因もある。しかし，その一方で， 有機化学，物理化学，高分子科学，光学，数学など では研究論文の増加が見られる。逆に医学分野の皮 膚学，泌尿器学などで減少が見られた。

それでは山形大学の現時点での大学全体の研究分 野の構成はどのような特徵があるか。論文数を単に 眺めるだけでは，例えば医学や生命科学は元来，一 人あたりの論文数が多い分野であり，大学としてそ こに重点があるのかはわからない。そのため，組織 の研究ポートフォリオ分析としていくつかの指標が 考えられる7)。一つは，顕示比較優位（RCA）指標で ある。下記のように，ある大学におけるi分野の論文 の割合を，日本の全論文におけるi分野の論文割合と 比較し，大学内での相対的な重点化度合いを計測す る。

$R C A(i)=A$ 大学の全論文数の中のi分野の論文の割合 日本の大学全体の全論文数の中のi分野の割合
また，研究の影響力については，一つには相対引 用度 $(R C I)$ が考えられる。RCIは，ある大学のi分野 の論文の平均引用数と，その分野の世界の論文全体 の平均引用数とを比較した指標である。しかし， RCI は大学内の論文の平均引用数を用いるため，たとえ 優れた論文がいくつかあったとしても，例えば大学 院生が多く，引用数の低い論文が多数産出されれば RCIは低くなってしまう注8)。前述の国立大学法人評価 のように，卓越した研究業績を示す必要がある場合 には，平均值を用いることは適当でなく，インパク トの高い論文がどれほどあるかを示すほうが適して いる。そのため，図10では横軸に全論文のRCAを用い， 縦軸には上位10\%論文のみに限ったRCAをとり，研 究分野をプロットした。プロット円の大きさは山形 大学の論文数に比例させている。

図からは，日本の平均と比して，重点化されており， 引用数の高い論文が多い分野として，高分子科学を はじめとする各種の化学分野，応用物理学，機械工学， 心臓疾患などの研究分野がある。他方，重点化度合 いは低くとも，引用数の高い論文の度合いが多い分 野（左上の象限）として，小児科，耳鼻咽喉疾患学， 海洋学が見られる。

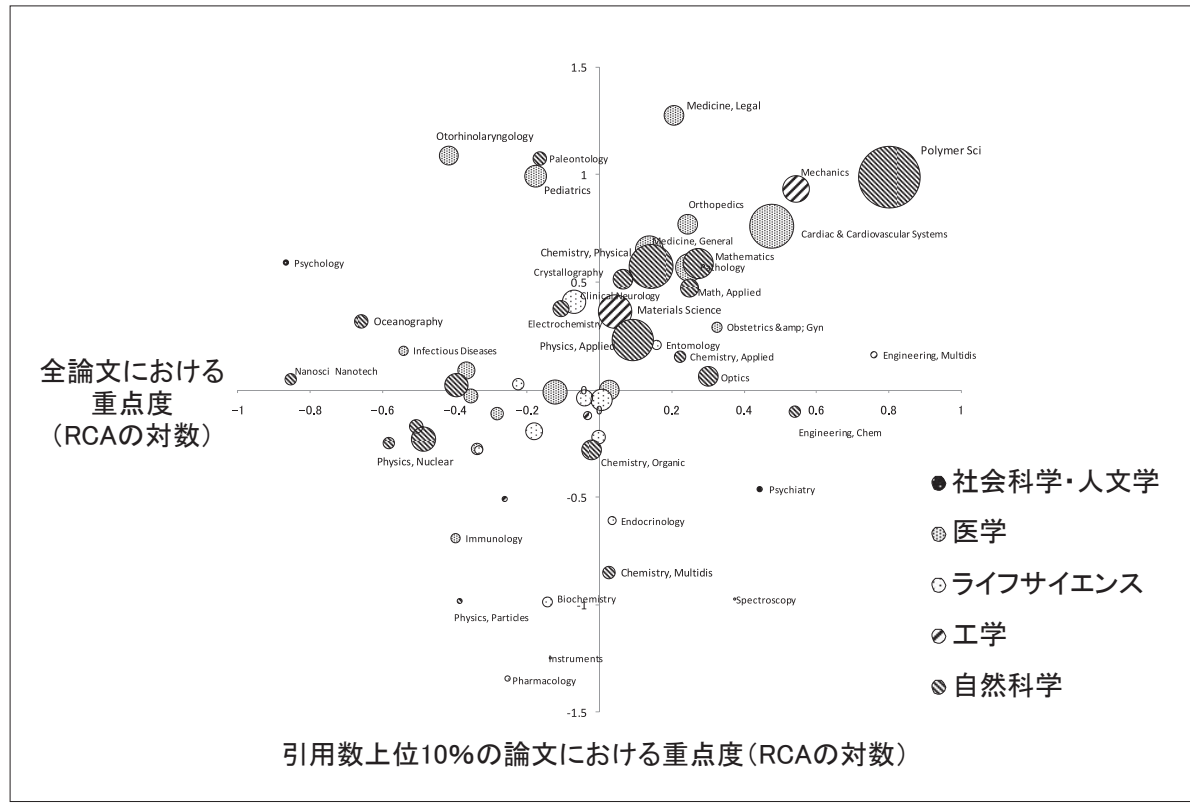

図10 山形大学の論文ポートフォリオ 
表2 山形大学のWoS論文のJDream II との照合結果

\begin{tabular}{|c|c|c|c|c|c|c|c|}
\hline \multirow{3}{*}{\multicolumn{2}{|c|}{$\begin{array}{c}\text { WoSにおおける山 } \\
\text { 形大学の論文 } \\
\text { (2007-08) }\end{array}$}} & \multicolumn{6}{|c|}{$\begin{array}{c}\text { 左記のうち, JDream II における山形大学の文献(全数6,147件) } \\
\text { と照合できた件数 }\end{array}$} \\
\hline & & \multirow[b]{2}{*}{ 総数 } & \multicolumn{5}{|c|}{ 記事区分の内訳 } \\
\hline & & & $\begin{array}{l}\text { a1 } \\
\text { 華詥 }\end{array}$ & a2 & b1 & b2 & 記事区 \\
\hline Article & 840 & $529(63.0 \%)$ & 392 & 97 & 7 & 4 & 29 \\
\hline Letter & 11 & $2(18.2 \%)$ & 0 & 2 & 0 & 0 & c \\
\hline Review & 21 & $11(52.4 \%)$ & 1 & 0 & 5 & 3 & 2 \\
\hline 計 & 872 & $542(62.2 \%)$ & 393 & 99 & 12 & 7 & 31 \\
\hline
\end{tabular}

しかし，WoSの分野分類の名称からは，その分野 の研究者でなければ一体何の研究であるのかを理解 しづらい。そのため， 解釈のためにはJSTのJDream II を併せて用いる方法が考えられる。すなわち，WOS は引用数を把握可能という利点があるが，分野分類 のみが統制されており，著者キーワードやアブスト ラクトの単語は多様であり，理解しづらい短所があ る。他方，JDream II は，引用数のデータはないが， 階層構造化された分野コードと統制された日本語シ ソーラスを使用可能である。そのため，その分野の 専門家でない日本人が概要を把握するための助けと なる。2つのデータベースに収録されている論文の マッチングは，論文のDOI，および/あるいは, ジャー ナルのISSNと巻とページで可能であり，一部はペー ジ数の表記摇れなどがあるため，論文名とのマッチ ングで補足することが必要となる。

山形大学が著者に入る論文は，2007-08年の2年間 を対象とした場合，WoSでは872件収録されていた (Article, Letter, Reviewのみ)。一方, JDream II (JSTPlus + JMEDPIus）では，日本語の論文や会議録の論文・ 予稿屯多数収録されているため，山形大学が著者に 入る文献は全体では6,147件，そのうちで主にWOSと のマッチングが可能となる，英語の逐次刊行物の文 献は770件であった。マッチングした結果，WoSの論 文の62.2\%がJDream II と照合可能であった（表2）。

表3には，引用数上位10\%論文について，シソーラ ス用語の共起による類似度でグループ化し，その主 なWOS分野とシソーラス用語を示している。前述の
ようにWOSの分野分類では，物理化学や高分子科学 が重点度合いが高かったが，その中には複数の研究 グループが含まれている。マスメディアでもしばし ば取り上げられる有機ELに関する研究や，コロイド 結晶の研究，リビングラジカル重合を用いた高分子 材料の研究などがある。また医学分野の心不全に関 する研究や，塑性に関する材料科学研究が見られる。 このようにすることで，大学の評価部門や研究戦略 部門などが定期的に研究活動の特徵を把握すること ができよう。

\section{5. おわりに}

研究活動は教員や研究者個人の創造性に強く依存 する活動であることに变わりはないが，それを前提 にしながらも大学はよりいっそう，組織として研究 力を分析し，その特徵を明確に表現し，資金獲得を 図っていくことが求められている。また，大学への

表3 引用数の高い論文群のJDream II におけるシソーラス用語

\begin{tabular}{|c|c|}
\hline 主なWoSの分野 & 主なシソーラス用語 \\
\hline 物理化学, 応用物理 & $\begin{array}{l}\text { 窒素複素環化合物, 発光ダイオード,イリジ } \\
\text { ウム錯体, 有機半導体, リン光, 芳香族縮合 } \\
\text { 化合物, Suzuki反応 }\end{array}$ \\
\hline 高分子科学,物理化学 & $\begin{array}{l}\text { 乾燥, 散逸,球, コロイド,シリカ, 型, 沈降, } \\
\text { 懸濁液, パターン形成, 表面構造 }\end{array}$ \\
\hline 高分子科学 & $\begin{array}{l}\text { リビングラジカル重合, 分子量, 分子量分布, } \\
\text { 機能性高分子, 相分離, 連鎖移動, ポアク } \\
\text { リル酸, 脂肪族カルボン酸, 水溶性高分子 }\end{array}$ \\
\hline 心臟病学 & ヒト,病態生理, 心不全 \\
\hline 材料学, 物性物理 & 塑性, 転位【結晶】 \\
\hline
\end{tabular}


運営費交付金などの公的資金の増加が期待しづらい 中で，どのような研究活動に大学の存在意義がある かを明らかにし，それをいっそう進めていくことに よる機能別分化を検討していくことが求められる。 しかし，そのような分析を行う人材は日本の大学の
中にはこれまで育成されておらず，その方法も未確 立な状態であろう。今後，大学や各種の機関で関心 を有する者が連携して，検討を進めていくことが必 要である。

\section{本文の注}

注1）第 2 期中期目標期間における国立大学法人評価の改善点（案).http://www.mext.go.jp/b_menu/ shingi/kokuritu/gijiroku/_icsFiles/afieldfile/2010/07/12/1295617_2.pdf, (accessed 2010-12-28).

注2） FAQ：会議録文献情報の統合に関して.トムソン・ロイター.http://www.thomsonscientific.jp/ support/faq/wos/cpci.shtml, (accessed 2010-12-28).

注3）図からも明らかなように中国の論文数の増加は著しい。中国論文の増加が収録対象雑誌の変化による ものか否かなど，その要因は富澤（2010）で詳細に分析されている4）。

注4）ハーフィンダール指標は次のように定義される。対象全体（本稿の場合は全論文数）の中のアクター iのシェアを $\mathrm{S}_{\mathrm{i}}$ すると，ハーフィンダール指標 $\mathrm{H}=10000 * \Sigma \mathrm{S}_{\mathrm{i}}^{2}$ である。

注5）機関のシソーラスは，筆者らでこれまで継続的に作成したものを利用した。詳細は山下，林（2010） を参照6)。

注6）カーネギー分類（Carnegie Classification）とは，1970年代より米国のカーネギ一教育振興財団が行っ ている米国内の大学に対する分類であり，学位授与状況によって，博士号授与大学（研究大学，博士・ 研究大学など)，修士号授与大学，学士号授与大学（教養型，多様な分野型など），特定領域大学，準 学士号授与大学などに分かれる。2005年からは，このような1種類の分類方法ではなく，6種類の異な る分類方法が用いられている。

注7）なお，複数機関の共著であっても1件と計測する整数カウントの場合には，減少でなく増加している。

注8）実際，山形大学の事例においては，高分子科学分野では引用数の高い論文がいくつか見られるが，そ の分野の山形大学の論文全体の引用数の平均值をとると日本全体の平均值とあまり变わらず，特徵が 見えにくい結果となった。

\section{参考文献}

1) 河田孝雄，星良孝. 41 万人会員の 26 学会が会長声明 論文数が激減，知の連山が必要. BTJジャーナル. 2010, vol. 5, no. 053, p. 7-12, http://biotech.nikkeibp.co.jp/btjjn/pdf/btjjn1005.pdf, (accessed 2010-12-28).

2) グローバル・リサーチ・レポート：日本.トムソン・ロイター . 2010, http://science.thomsonreuters.jp/ press/releases/GRR-Japan, (accessed 2010-12-28).

3) 阪彩香, 桑原輝隆. 科学研究のベンチマーキング2010一論文分析でみる世界の研究活動の変化と日本の状 況一.文部科学省科学技術政策研究所, 2010, 調査資料192, 132p.

4) 富澤宏之. “科学知識生産の世界地図の刷新”. 研究・技術計画学会第25回年次学術大会講演要旨集. 東京, 2010-10-09/10, 研究・技術計画学会, 2010, p. 721-724.

5）林隆之, 富澤宏之. 日本の研究パフォーマンスと研究実施構造の変遷. 大学評価・学位研究. 2007, no. 5, p. $55-73$. 
6) 山下泰弘, 林隆之. “研究機関シソーラスの構築とそれに基づく大学の研究活動の定量的評価”. 研究・技術 計画学会第25回年次学術大会講演要旨集. 東京, 2010-10-09/10, 研究・技術計画学会, 2010, p. 506-509.

7) 藤垣裕子, 平川秀幸, 富澤宏之, 調麻佐志, 林隆之, 牧野淳一郎. 研究評価・科学論のための科学計量学入門. 丸善, 2004, 224p.

\section{Author Abstract}

Universities in Japan are required to conduct self-analysis of own research activities, confronting the institutionalization of university evaluation, competitive organizational-level funding, and requirement for mission differentiation. In this article, we discuss what kind of self-analysis is required for university through explanation of the evaluation system of national universities in Japan. Then bibliometric analysis is conducted to explore the change of research performance and concentration of research activities after incorporation of national universities. The methods of self-analysis within universities are proposed from a case-study on diversity and priority of research.

\section{Key words}

research activities in university, research evaluation, bibliometrics, diversity, portfolio analysis 